\title{
What is the Added Value of the Concept of the "Essence" of EU Fundamental Rights?
}

\author{
Mark Dawson ${ }^{1}$, Orla Lynskey ${ }^{2}$ and Elise Muir ${ }^{3}$ \\ ${ }^{1}$ Hertie School of Governance, ${ }^{2}$ London School of Economics and Political Science and ${ }^{3}$ KU Leuven
}

(Received 01 May 2019; accepted 30 May 2019)

\begin{abstract}
This Article introduces our Special Issue by posing a central question: What is the added value of the increasing prominence of the concept of the "essence" of fundamental rights in EU law? It will address this larger question in four steps: First, by examining the function of the concept in EU law and the methods for its derivation; second, by summarizing how its application diverges across EU—and international—law; third, by outlining some enduring difficulties with the essence concept; and finally, by reflecting on its future role in EU law, including its impact on other sites of legal authority-such as domestic fundamental rights, the political institutions of the EU, and international human rights law. As the other articles of this issue demonstrate, while there is not yet a coherent approach to deriving and understanding the essence of rights across the fundamental rights the EU must protects, the essence concept plays an increasingly significant role in demarcating the boundaries between the EU's legal and political orders and between overlapping sites of legal authority. Recent developments - such as the rule of law "crises"-are likely to further amplify the importance of "essence" to EU law practice and scholarship.
\end{abstract}

Keywords: EU law; fundamental rights; essence of rights

\section{A. The Rise of a New Concept in EU Law}

The European Union acquired its own written charter of fundamental rights at the turn of the last century. The text of the Charter of Fundamental Rights of the EU ("CFEU" or "the Charter") resulted from a Convention ${ }^{1}$ and was solemnly proclaimed by the European Parliament, the Council and the Commission in 2000. Since 2009, the Charter has the same legal value as the EU Treaties. ${ }^{2}$ In its Article 52(1), the text of the Charter specifies:

Any limitation on the exercise of the rights and freedoms recognized by this Charter must be provided for by law and respect the essence of those rights and freedoms. Subject to the principle of proportionality, limitations may be made only if they are necessary and genuinely meet objectives of general interest recognized by the Union or the need to protect the rights and freedoms of others. ${ }^{3}$

\footnotetext{
${ }^{1}$ See Richard Bellamy and Justus Schönlau, The Normality of Constitutional Politics: An Analysis of the Drafting of the EU Charter of Fundamental Rights, 11 Constellations 412 (2004); Gráinne de Búrca, The Drafting of the European Union Charter of Fundamental Rights, 26 EUR. L. REv. 126 (2015).

${ }^{2}$ Charter of Fundamental Rights of the European Union art. 6(1), Oct. 26, 2010, 2012 O.J. (C 326) [hereinafter TEU].

${ }^{3} I d$. at art. 52(1). 
Despite its presence in the EU legal order for almost two decades, the concept of the "essence" of EU Charter rights remains both under-utilized and under-scrutinized. The concept has remained dormant in the Court of Justice of the European Union's ("CJEU" or "the Court") case law until recently; while the Court frequently paid lip-service to it as a constituent limb of Article $52(1)$ in its judgements, ${ }^{4}$ it was only in Schrems ${ }^{5}$ in 2015 that the concept became fully operational. It was in Schrems that the Court deemed a measure to encroach upon the essence of fundamental rights for the first time-in situ the rights to respect for private life and to effective judicial protection. ${ }^{6}$ Equally, although academic literature has acknowledged the incorporation of the concept of "essence" into the Charter, its inclusion has not yet been the subject of much critical interrogation. ${ }^{7}$

It is in light of this practical and theoretical void that this collection of Articles should be considered. In particular, key questions regarding the concept of essence still need to be addressed: What are the origins of its "constitutionalization"? How does one define the "essence" of a fundamental right? What are the functions of the concept in the EU legal order? And what added value - if any-does such a concept bring? These questions constitute the core research agenda of this special issue.

To answer these questions, the concept of "essence" has been approached both from an external non-EU perspective and an internal EU perspective. From an external perspective, Thielbörger examines and analyzes the concept of "essence" in public international law, ${ }^{8}$ while Van Drooghenbroeck and Rizcallah consider how the concept is approached in the jurisprudence of the European Court of Human Rights (ECtHR). ${ }^{9}$ These articles provide us with input on how other legal orders address the question of the "essence of fundamental rights," including how the content and function of the concept is defined and articulated and, in some instances, what surrogates are used in its place.

Viewing the concept through an internal EU lens offers a different vantage point. In the opening article of the issue, Koen Lenaerts, President of the CJEU, sets out his personal views on the concept of essence. In Lenaerts' view, the essence of a right is only compromised "where the limitation in question empties those rights of their content or calls their very existence into question." 10 Furthermore, Lenaerts suggests that the "hard nucleus" of every fundamental right that constitutes its essence ought to be absolute. In this way, a measure compromising the essence of a fundamental right is incompatible with the Charter, without there being space for further balancing of interests. Nevertheless, a measure not compromising the essence of a fundamental right may still be incompatible with the Charter if it does not comply with other conditions set out in Article 52(1) of the Charter, such as proportionality. Lenaerts further elaborates on how the case law of the CJEU ${ }^{11}$ can be reconciled with the proposed approach.

The internal articles that follow elaborate on the conceptual and practical issues raised by the concept of essence in the EU legal order. From a theoretical perspective, critical questions remain unanswered: What is meant by the "essence" of EU Charter fundamental rights? Who should

\footnotetext{
${ }^{4}$ See, for instance, the early data protection judgement in Joined Cases 92 \& 93/09, Volker und Markus Scheke GbR v. Land Hessen, 2010 E.C.R. I-11063 [hereinafter Scheke]. The Court repeated the Article 52(1) formula but, in its analysis, considered only whether the measure was provided for by law and proportionate, excluding any further reference to the "essence" of the rights engaged.

${ }^{5}$ Case C-362/14, Schrems v. Data Protection Comm'r (Oct. 6, 2015), http://curia.europa.eu/.

${ }^{6} I d$. at paras. $94-95$.

${ }^{7}$ But see Maja Brkan, The Concept of Essence of Fundamental Rights in the EU Legal Order: Peeling the Onion to its Core, 14 Euro. Const. L. Rev. 332 (2018).

${ }^{8}$ Pierre Thielbörger, The "Essence" of International Human Rights, 20 GERMAN L.J. 924 (2019).

${ }^{9}$ Sébastien Van Drooghenbroeck \& Cecilia Rizcallah, The ECHR and the Essence of Fundamental Rights: Searching for Sugar in Hot Milk?, 20 German L.J. 904 (2019).

${ }^{10}$ Koen Lenaerts, Limits on Limitations: The Essence of Fundamental Rights in the EU, 20 GERMAN L.J. 779 (2019).

${ }^{11}$ By opposition to the General Court. Id.
} 
decide on what the essence of a fundamental right is? What function does the concept perform in the EU legal order and how has this historically evolved? Gentille and Tridimas go about answering several of these questions in their contribution, which proposes three distinct understandings of the concept of essence and considers how the "essence" of a right might be distinguished from its peripheral dimensions. ${ }^{12}$ The remaining articles build on these theoretical foundations by approaching the concept in an applied manner. These articles identify and analyze how the concept is brought to bear across a range of EU Charter rights, namely the rights to respect for private life and data protection (Brkan); the right to non-discrimination (Muir); the right to intellectual property (Husovec); and the right to an effective remedy (Gutman).

Thus, as the definition, methodological approach and constitutional function of the concept of essence are still in the process of being shaped, this Special Issue provides an opportunity to offer input in this process from a theoretical and applied perspective. What emerges from these articles is a mix of approaches to defining the content and functions of the "essence" of rights. ${ }^{13}$ In light of this differentiation, we seek to explore the way the Court has articulated these various approaches to identify - or exclude - an interference with the concept of essence. ${ }^{14}$ This being so, we offer some critical reflections on the benefits and challenges of incorporating this concept in the EU legal order ${ }^{15}$ before concluding by reflecting upon its potential future implications. ${ }^{16}$

\section{B. Defining the Content and Functions of the "Essence" of Rights}

\section{Methods to Define the Substantive "Essence" of Charter Rights}

Meaningful legal concepts require methodological foundations. In simple terms, if there is to be an "essence" of fundamental rights, there must also be a method of identifying this essence. Choices between methodological approaches must therefore be made.

A first choice would be between deductive and inductive methods. According to the deductive approach, in order to identify the essence of a right in practice it is necessary to understand what this essence would look like ex ante in the abstract. In contrast, according to an inductive approach, it is only through the development of case-law-and the application of fundamental rights standards to specific facts - that we can learn whether the essence of a fundamental right has been breached ex post.

A second methodological choice is between objective and subjective approaches to identifying the essence of rights. Tridimas and Gentille suggest that in order to identify the essence of a right - which encompasses the "essential attributes of an entitlement that define its nature as a distinct right" - this interpretation must be guided by the specific objectives of the right and its placement and significance in the overall system of fundamental rights protection. ${ }^{17}$ This approach could, it appears, be either inductive or deductive. Yet, it also presents another methodological choice between an institutional—or objective — and a subjective approach. The essence of the right could be defined subjectively - for instance, from the point of view of the right holder-or objectively, from the point of view of the function of rights within the constitutional polity. Tridimas and Gentille suggest that the subjective approach may lead to an overly broad understanding of essence; for instance, imprisonment by definition defeats the right to liberty just as deportation defeats the EU right to free movement. ${ }^{18}$ Similarly, Van Drooghenbroeck and Rizcallah note two

\footnotetext{
${ }^{12}$ Takis Tridimas \& Giulia Gentille, The Essence of Rights: An Unreliable Boundary?, 20 German L.J. 794 (2019).

${ }^{13}$ Discussed infra Section B.

${ }^{14}$ Discussed infra Section C.

${ }^{15}$ Discussed infra Section D.

${ }^{16}$ Discussed infra Section E.

${ }^{17}$ Tridimas \& Gentile, supra note 12.

${ }^{18}$ Tridimas \& Gentile, supra note 12.
} 
"classically opposed" approaches to "core."19 From an institutional perspective they suggest that the essence of a right is infringed only when such a right loses its meaning for all or nearly all individuals and not just a limited number of people. ${ }^{20}$ In contrast, from a subjective perspective, the right as an institution may be unimpaired by an infringement yet its substance may be rendered void for one individual.

A third choice would be to distinguish between micro and macro approaches to the identification of essence. While the institutional or subjective distinction mentioned above relates to who the essence of the right is defined in relation to, this choice relates to the "level" at which we identify essence. We might consider whether the essence of fundamental rights is relevant to each and every individual right, or whether the essence is something that relates to the system as a whole. Even when conceiving the essence as relevant to the system as a whole, rather than individual rights, this can manifest in different ways. On the one hand, it could be suggested that in identifying the essence of rights it is preferable to consider the EU Charter rights holistically as pursuing a larger moral goal. This deductive approach would concern itself not with whether a particular right is breached, but rather with whether an infringement goes to the core of the moral principles that underline the EU's fundamental rights system, taken as a whole. On the other hand, Thielbörger suggests that in public international law essence has a dual function: At the micro level it relates to identification of the core of each individual human right, but equally it can relate at the macro level to the identification of "which human rights are most essential within the existing human rights canon." ${ }^{11}$ Thus, for these rights, the entire right is considered essential, meaning that their scope and their essence is identical.

A fourth choice is whether or not to identify the essence or essential content of each right. An alternative is proposed by Lenaerts as he argues that the "essence" of a right is compromised "where the limitation in question empties those rights of their content or calls their very existence into question." 22 This suggests that the essence of a right is interfered with when the right is extinguished or abolished. In that case, there is no need to flesh out the content of the "essence" of the right. This approach is very similar to the way the Court has historically approached restrictionsbefore the Charter became a point of reference-which undermine the "very substance" of fundamental rights, as in Karlsson, ${ }^{23}$ mentioned in the explanations on Article 52(1) of the Charter. Moreover, as Van Drooghenbroeck and Rizcallah note in their article, the ECtHR has relied upon similar reasoning in some of its jurisprudence. ${ }^{24}$ In Regner v. Czech Republic, ${ }^{25}$ Article 17 of the European Convention on Human Rights ("ECHR") was construed by Judge Serghides to support the conclusion that "under no circumstances is the role of an exception to a right under the Convention to render the right ineffective, still less to extinguish it, and no one, including the State, can invoke an exception in order to destroy a right." ${ }^{26}$

\section{The Function of the Concept of "Essence"}

Beyond identifying the "essence" of rights, it is necessary to consider what role that concept plays in the context of Article 52(1) EU Charter. When considered on an individualized right-by-right basis, as opposed to holistically, the majority of the doctrine distinguishes between absolute and relative functions for the concept of essence.

\footnotetext{
${ }^{19}$ Van Drooghenbroeck \& Rizcallah, supra note 9.

${ }^{20} I d$.

${ }^{21}$ Thielbörger, supra note 8.

${ }^{22}$ Lenaerts, supra note 10.

${ }^{23}$ Case C-292/97, Kjell Karlsson and Others, 2000 E.C.R. I-02737.

${ }^{24}$ Van Drooghenbroeck \& Rizcallah, supra note 9.

${ }^{25}$ See Regner v. Czech Republic, App. No. 35289/11 (Sept. 19, 2017), http://hudoc.echr.coe.int/.

${ }^{26} I d$. at para. 50 .
} 
According to the absolute theory, the essence of a right is its "untouchable core." 27 In this sense, essence is an absolute requirement; as Gentille and Tridimas put it, this means that "a sine qua non for a restriction to be constitutional is that it must not affect the essence of a right." 28 As such, if the essence of a right is interfered with, the interference cannot be justified on proportionality grounds. Essence is distinct from proportionality and "proportionality begins where essence stops." 29

The relative theory, by contrast, does not require such a strict delineation between proportionality and essence. Rather, pursuant to this theory, "any proportionality inquiry must take on board the heightened respect that the core element of a right deserves." 30 That view adds little to the traditional proportionality test whereby the degree of intrusion into a right is an inherent part of the analysis.

One can expect the concept of "essence" to be particularly useful in three contexts at the EU level. First, the concept may impact on the possibility to invoke the related Charter right in horizontal disputes. In this view, the essence of the right would be "sufficient in itself and does not need to be made more specific by other provisions of EU or national law in order to confer on individuals a right on which they may rely as such." ${ }^{31}$ As a consequence, the essence of such a right applies also in disputes between private parties. Second, and as will be discussed further below, ${ }^{32}$ the concept of "essence" may be used to delineate the respective functions of the judge and the legislator in the definition of fundamental rights as - in the view of the author-secondary EU law or national law may only "determine non-essential elements" of the fundamental right. ${ }^{33}$ Third, the "essence" may be used to articulate the tension between fundamental rights and mutual trust. In the $L M$ case, for instance, it is the "essence" of the fundamental right to a fair trial that was used to reconcile the concern for fundamental right protection with the imperatives of mutual trust in the area of freedom security and justice. ${ }^{34}$

Other ways of understanding the function of essence of the fundamental right go beyond Article 52(1) of the Charter. For their part, Van Drooghenbroeck and Rizcallah claim that the ECtHR has used the concept of essence to pursue further functions beyond its role as a "limit on limits" in the scrutiny of human rights infringements. Strikingly, they suggest that the concept of essence or substance or core of fundamental rights-terms used interchangeably in the ECtHR's case law-has been utilized as a vehicle to expand the ECHR's sphere of protection in order to ensure its practical utility. Here, Van Drooghenbroeck and Rizcallah note that the concept of the "very substance" of rights has been used to expand the ECHR's material and territorial scope. For instance, they demonstrate that the freedom of association has been extended beyond its textual positive framing to enshrine its negative aspect by relying on this concept. Therefore, in Young, James and Webster, the Court held that to construe this Article 11 right "as permitting every kind of compulsion in the field of trade union membership would strike at the very substance of the freedom it is designed to guarantee." 35

In the context of public international law, Thielbörger provides a further function for the "essence" of rights. ${ }^{36} \mathrm{He}$ argues that identifying the "essence" of rights may relate not to the limitation of the right through action, but rather to identifying a minimum core of rights whose

\footnotetext{
${ }^{27}$ Maja Brkan, The Essence of the Fundamental Rights to Privacy and Data Protection: Finding the Way Through the Maze of the CJEU's Constitutional Reasoning, 20 GERMAN L.J. 864 (2019).

${ }^{28}$ Tridimas \& Gentille, supra note 12.

${ }^{29}$ Tridimas \& Gentille, supra note 12.

${ }^{30}$ Tridimas \& Gentille, supra note 12.

${ }^{31}$ Lenaerts, supra note 10.

${ }^{32}$ See infra Section D(III).

${ }^{33}$ Lenaerts, supra note 10 .

${ }^{34}$ This is developed further in infra Section D(III).

${ }^{35}$ Young, James, and Webster v. UK, App. No. 7601/76, para. 65 (August 13, 1981), http://hudoc.echr.coe.int/.

${ }^{36}$ Thielbörger, supra note 8.
} 
realization requires state action. ${ }^{37} \mathrm{He}$ observes that for socio-economic rights in public international law, the concept has become "most relevant in terms of guaranteeing an essential level of protection that States have to uphold immediately and independent of potential resource limitations." 38 Thielbörger describes this "flavor of essence" as creating obligations that are "immediately and resource-independently owed" and that, as a result, are supposed to be more justiciable for individuals. ${ }^{39}$ The concept of essence may therefore serve a similar function in EU law in the context of analogous rights.

\section{Determining When the "Essence" of a Fundamental Right is Breached: In Search of Coherence in the Court's Case Law}

Following on from these abstract observations regarding the potential content and functions of the "essence" in EU law, one may ask: Has the Court been relying on these different approaches in a coherent manner to identify interferences with the essence of a right within the meaning of Article 52(1) of the Charter? Without providing an exhaustive analysis, and instead inviting our reader to further look at our various contributions, it is notable that the Court has until today used different techniques to identify interferences with the essence of a right. As will now be explained, these diverging approaches illustrate varying understandings of the methods for the definition of the content of the concept as well as of its function.

Thus, for instance, if the "essence" is deemed to be affected when the right risks being extinguished or abolished, the function of the "essence" may be to ensure absolute protection. In other words, a threat to the "essence" of a right understood as its very existence excludes the possibility of balancing divergent interests and calls for absolute protection. The Court's approach to the right to judicial protection in Schrems seems close to this approach, where the lack of access to any judicial remedy for individuals affected by decisions regarding the transfer of data in effect deprived the right to effective judicial protection of any practical meaning. ${ }^{40}$ This approach has the advantage of better taking into account the specificities of each right and the legal and political context in which it has been developed without having to delve into its specific content.

An alternative technique for identifying an interference with the essence of rights is to look not at extinction of the right but at the breadth of the breach. In this case, the essence might be violated because of the degree and scale of a rights violations. An example discussed in Muir's article is Léger. ${ }^{41}$ The limited scope of the practice of removing men who have sex with other men from the range of available blood donors was seen as meaning that the "essential contents" of the right to non-discrimination were not as such called into question. ${ }^{42}$ The key test here is the degree of the violation and whether actors violating rights have made any meaningful efforts to limit the range and nature of their infringements. In that example, as noted by the author, the Court does not actually define the substantive content of the "essence." Furthermore, as the "essence" is not encroached upon, the case also provides little guidance as to what the function of the concept could have been.

This contrasts with the approach chosen by the Court in Schrems regarding the fundamental right to respect for private life, whereby an effort was made to clarify the substantive content of the "essence" of the right. The issue at hand was not only the lack of judicial remedies, but also the absence of safeguards ensuring that "the content of electronic communications must be regarded

\footnotetext{
${ }^{37}$ Thielbörger, supra note 8 .

${ }^{38}$ Lenaerts, supra note 10.

${ }^{39}$ Thielbörger, supra note 8 .

${ }^{40}$ Schrems, supra note 5 , at para. 95 .

${ }^{41}$ Elise Muir, The Essence of the Fundamental Right to Equal Treatment: Back to the Origins, 20 German L.J. 817 (2019).

${ }^{42}$ Case C-528/13, Geoffrey Léger v. Ministre des Affaires sociales, para. 54 (Apr. 29, 2015), http://curia.europa.eu.
} 
as compromising the essence of the fundamental right to respect for private life." ${ }^{\prime 3}$ In such a scenario, the Court adopted an inductive method of discovery, relying on its earlier case law in Digital Rights Ireland..$^{44}$ In that context, the function of the concept of essence constitutes an application of the absolute theory, whereby the Court concludes a breach of the fundamental right swiftly after observing a breach of the "essence."

Brkan, in her contribution, proposes yet another approach: A generalized method for determining infringements of the essence of rights in fundamental rights jurisprudence. ${ }^{45}$ She proposes a two-step test to analyze interference. The first step is to verify whether the interference with the fundamental right makes it impossible to exercise this right; the second step is to ensure that there are no legitimate reasons in the public interest that can override the alleged interference. ${ }^{46}$ This proposed technique, like some of those noted above, is predicated on a particular vision of the method for the definition of the substantive content of the "essence" as well as of the function of the concept of essence. Through the first limb of the test, one essentially ascertains whether the intrusion in question calls into question the fundamental right as such and may extinguish it. In other words, does the intrusion abolish the right? Through the second limb of the test, one queries whether the interference can be subject to overriding justifications and is thus amenable to "proportionality" reasoning. If it is, then there is no interference with the essence. If it is not, the essence of the right as well as the right itself is breached. This thus endorses the absolute approach to "essence."

What forcefully emerges from the overall set of contributions as well as from the selected overview above is that, to date, the case law of the Court on the concept of "essence" in the analysis of limitations to Charter rights still lacks coherence. More specifically, there is a lack of conceptual clarity on how to define the content of the "essence" of a given fundamental right as well as on the function of the said concept.

\section{The "Essence" of Rights: A Critical Appraisal}

The difficulties in coherently defining the concept of "essence" and understanding its functions suggests underlying critical challenges. Van Drooghenbroeck and Rizcallah highlight that the judges of the ECtHR have explicitly noted the uncertainties raised by the concept of "essence" or "very substance" of rights in their judgements, notably regarding their definition and function. ${ }^{47}$ They conclude, rather pessimistically, that the concept has been overworked suggesting, in particular, "that there is no reason that the Court of Strasbourg should succeed where other judges, investigating the respect of constitutional or conventional instruments enshrining the intangibility of the essence of rights much more explicitly, continue to fail." 48 What, then, are the key conceptual challenges to be faced in the context of EU law ${ }^{49}$

\section{The Challenges of Defining the Substantive "Essence" of Rights}

The first challenge relating to the concept of essence is one of identification and definition: What methodology should be employed to identify essence; does every right have an "essence" and, if so, what is the "content" of this essence? As discussed above, in identifying the essence of rights, one

\footnotetext{
${ }^{43}$ Schrems, supra note 5, at para. 94.

${ }^{44}$ Joined Cases 293 \& 594/12, Digital Rights Ireland Ltd. v. Minister for Commc’n (Apr. 8, 2014), http://curia.europa.eu.

${ }^{45}$ Brkan, supra note 27.

${ }^{46}$ Brkan, supra note 27.

${ }^{47}$ Van Drooghenbroeck \& Rizcallah, supra note 9.

${ }^{48}$ Van Drooghenbroeck \& Rizcallah, supra note 9.

${ }^{49} \mathrm{On}$ some conceptual objections to the essentializing nature of the essence of rights, see ROBERT ALEXY, A THEORY OF Constitutional Rights 192-96 (Oxford Univ. Press 2010).
} 
must make methodological choices, most notably between the adoption of an inductive or deductive approach to this endeavor.

The starting point for the inductive approach is the individual and their encounter with the legal order. EU fundamental rights carry an important individualizing dimension, demanding that rights violations be understood on a case-by-case basis, taking all the relevant facts and context into account. Given that the Charter remains a relatively young document, there is some sense in elaborating the essence on a gradual basis rather than all at once, taking national and legislative developments into account. Indeed, this is consistent with how the more mature general principles of EU law have been developed. Moreover, as our contributions demonstrate, this approach most accurately describes the approach the Court has taken to the notion of "essence" thus far-with highly uneven levels of reference to the essence of rights across different fields.

As the articles also demonstrate, however, the inductive approach leads to two particular difficulties. The first relates to the difficulty of discovering the "core" as opposed to "peripheral" elements of particular rights. For instance, Muir evidences the difficulties in grappling with an essence of equality rights that meaningfully narrows the "standard formulae" which has been applied by the EU Courts to non-discrimination in the past. ${ }^{50}$ She argues that the very architecture of the fundamental right to equal treatment prevents the definition of an essential content from being protected in absolute terms; that fundamental right is instead inherently open to a balancing of competing interests. ${ }^{51}$ This difficulty in identifying the content of a fundamental right is exacerbated by the diversity of the rights in the EU Charter, even within a single Charter provision. For example, Gutman observes that "there is not just one singular essence of the fundamental right to an effective remedy and to a fair trial embodied in Article 47 of the Charter." 52 Rather, she observes, each paragraph of that article contains elements informing the essence of the fundamental right. In contrast, for other rights the entirety of a given right seems to overlap with its essence - as Lenaerts discusses in his contribution. ${ }^{53}$

The second difficulty stemming from the inductive approach is its ostensibly arbitrary nature. In Jacobellis $v$ Ohio, Justice Potter Stewart infamously observed that while obscenity was difficult to define in advance, he knew it when he saw it. The inductive approach to the identification of essence might be said to reflect a similar logic. Indeed, Brkan observes that the Court's case law on this issue "can be depicted as a muddled maze where the final destination remains concealed due to reasoning that is full of meanders and unpredictable curves." 54

By tying the essence of fundamental rights to an overarching view of the most "fundamental" moral goals and principles in the EU legal order, and conducting this exercise ex ante, the deductive approach cannot be accused as being so arbitrary or unpredictable. As such, there are clear rule of law advantages to such an approach: If all "essence" violations are understood using a single deductive approach, the individual — and state-may be able to garner clearer legal expectations regarding when the essence of a given right has been engaged.

Yet, the deductive approach is not without its pitfalls either. This approach is most visible in the German legal tradition, where reliance on essence relates to the overarching orientation of the German constitutional order towards protecting the fundamental autonomy and human dignity of the individual. ${ }^{55}$ It is from this moral starting point that the "essence" of any breach can be identified-for example, the essence of a given right will be breached when a rights violation

\footnotetext{
${ }^{50}$ Muir, supra note 41.

${ }^{51}$ Muir, supra note 41.

${ }^{52}$ Kathleen Gutman, The Essence of the Fundamental Right to an Effective Remedy and to a Fair Trial in the Case-Law of the Court of Justice of the European Union: The Best is Yet to Come?, 20 GERMAN L.J. 884, Section II (2019).

${ }^{53}$ Lenaerts, supra note 10.

${ }^{54}$ Brkan, supra note 27.

${ }^{55}$ See e.g., WALter LeISNER, GRUNDrechte Und PRIVATRECHT (Beck 1960); Juliane Kokott, Grundrechtliche Schranken und Schrankenschranken, in Handbuch Der Grundrechte IN Deutschland und Europa (Detlef Merten \& Hans-Jürgen Papier eds., 2004).
} 
threatens this fundamental autonomy in a particularly serious manner. When drawing inspiration from this approach for the EU legal order, fundamental queries arise: Most evidently, to what extent do European legal orders have a sufficiently convergent common tradition of rights such that $E U$ fundamental rights can equally be tied to an over-arching and unitary moral goal or purpose $?^{56}$ The danger is that the essence of rights is deduced using different lenses depending on the moral standpoint of the judges making the decision. The Charter does not itself clearly identify the overriding goals of EU fundamental rights protection-while some may connect it to human dignity, one's view of the goals of EU fundamental rights may vary depending on one's view of human rights protection more generally or of the EU as an organization. ${ }^{57}$ For instance, for some, the EU may be seen as a political Union, connecting the Charter more closely to the democratic and liberal character of EU states, thus demanding the "essence" of rights be understood in this tradition. For others, the Charter's goal may be more easily articulated in terms of restraining the power of EU actors vis-à-vis the individual, demanding a quite different view of which moral principles should guide EU fundamental rights as a whole-and hence their essence. In practice, this disagreement could work against the perceived "rule of law" advantages of a deductive approach, fragmenting the case-law and hence undermining fixed legal expectations.

Similarly, a powerful argument against reliance on the concept of "essence" is the virtual impossibility of defining the content of the essence of fundamental rights according to a consistent methodology. In light of the analysis of the Court's cases performed by most of our authors, it could be argued that there is hardly any coherent approach to deriving an essence of EU fundamental rights across the entire landscape of EU fundamental rights law. Even the contribution by Lenaerts, that provides a powerful attempt at bringing together the Court's case law, focuses on the consequences of relying on the concept of "essence" of a right, providing only sparse details on the methodology used to identify the "essence" as such.

The answer to the question of whether each right in the EU Charter has an essence might be equally contentious. In her article, Brkan alludes to a "deep conceptual disagreement" 58 between Member States as to the necessity of the concept in a constitutional order protecting fundamental rights. She suggests that "the constitutional orders of various Member States seem to differ on the question whether every fundamental right possess an untouchable core and whether a separate protection of such core is necessary or even appropriate." 59

In theory, the right-by-right inductive approach mentioned above seems to set aside the important differences between Charter rights, ranging from rights which are relatively absolute in nature to those rights explicitly seen as "principles" to be aspired to, rather than hard, justiciable claims whose core essence must be defended against external infringement. Yet, it does seem that in practice, the Court does not adopt such a systematic approach to the concept. For instance, Husovec observes that the concept of essence is "hardly applied" in the EU Courts' case law on the Article 17 (2) right to intellectual property. ${ }^{60}$ Moreover, the Court has seemingly indicated in its jurisprudence that no such "essence" exists. In Scarlet Extended it held that "[ $\mathrm{t}]$ here is, however, nothing whatsoever in the wording of [Article 17(2)] or in the Court's case-law to suggest that that right is inviolable and must for that reason be absolutely protected." 61 There is therefore real doubt about

\footnotetext{
${ }^{56} \mathrm{We}$ are most grateful to Leonard Besselink for sharing his views on this point during his presentation on "Is the Concept of the Essence of Fundamental Rights Mirrored in European Domestic Constitutional Law?" on the occasion of the conference on which this Special Issue is based.

${ }^{57}$ On this long-standing debate, see Piet Eeckhout, The EU Charter of Fundamental Rights and the Federal Question, 39 COMmON MKT. L. Rev. 945 (2002).

${ }^{58}$ Brkan, supra note 27.

${ }^{59}$ Brkan, supra note 27.

${ }^{60}$ Martin Husovec, The Essence of Intellectual Property Rights Under Article 17(2) of the EU Charter, 20 GERMAN L.J. 840 (2019)

${ }^{61}$ Case C-70/10, Scarlet Extended SA v. Société belge des auteurs, compositeurs et éditeurs SCRL (SABAM), 2011 E.C.R. I-11959, para. 43.
} 
whether each and every right in the Charter could meaningfully be said to carry such a "core" capable of being "emptied" or "hollowed-out" in the first place.

These definitional challenges call the value of the concept of essence in the EU legal order into question. This concept is arguably meaningless in the sense of being sufficiently elastic and malleable that it has no real boundaries. Certainly, the historical contingency of the "essence" concept is borne out by the articles to this Special Issue, with some areas-such as data protection-carrying a relatively well-developed notion of essence and others - such as asylum-carrying no similarly developed notion. This could be seen as counter-intuitive given the close links between an area like asylum and rights of an absolute or non-retractable nature, such as the right to life or freedom from inhuman and degrading treatment. In that sense, Tridimas and Gentile are critical of the Court's past case law on the relative protection of the fundamental rights of asylum seekers in the context of the Dublin system that they deem to constitute the "very antithesis of essence"; it deprives "human rights from their character as rights of the individual." 62

On the other end of the spectrum, numerous social rights contained in the Charter have been seen by the Court as having limited justiciability such that applying a notion of "essence," as now proposed by Lenaerts in relation to the fundamental right to annual paid leave, would constitute a highly innovative approach. It is to be noted that, to that effect, Lenaerts does not sketch out a method to define the substantive content of the "essence" of the fundamental right at hand. Instead, he proposes a method of identification based on the risk of extinguishing the right - a threat to the "very existence" of the right. ${ }^{63}$ In this sense, it may simply be too difficult to identify a specific method to define the substantive content of the notion of "essence" that would apply to the diverse range of fundamental rights that the EU legal order is designed to protect.

\section{The Challenges of Defining the Substantive "Essence" of Rights}

The function of the concept of "essence" to examine limitations of fundamental rights also raises important questions. There may be reasons to argue that the idea of "essence" is needed given the limitations of other doctrines used by the Court to protect EU fundamental rights. One key example here is proportionality: A doctrine that is by now a ubiquitous tool in human rights litigation, in Europe and beyond. For its detractors, proportionality's main outcome is to empower judges by endowing them with a task of gauging the suitability and necessity of public policies that is normally reserved to the political branch. ${ }^{64}$ Alternatively, proportionality has been posited as a technical device used to shield judges from the political implications of their rulings and hence damaging to the moral basis of international human rights law. ${ }^{65}$ By limiting such balancing, the notion of an "essence" of rights could be seen as fitting more appropriately to the counter-majoritarian foundations of human rights-for example, the notion that rights refer to foundational moral claims, to be assessed independently of the normal process of interestbalancing found in the political process.

As articulated in Lenaerts's article, "the essence of a fundamental right operates as a constant reminder that our core values as Europeans are absolute and, as such, are not up for balancing." 66 The notion of essence thus reflects the limits of balancing either for particular Charter rights or for the EU fundamental rights order more generally. Similarly, writing in the context of public international law, Thielbörger observes that most interpretations have endorsed the "absolute"

\footnotetext{
${ }^{62}$ Tridimas \& Gentile, supra note 12.

${ }^{63}$ Lenaerts, supra note 10.

${ }^{64}$ Alec Stone-Sweet and Jud Mathews, Proportionality Balancing and Global Constitutionalism, 47 COLUM. J. OF TRANSNAT'L L. 72 (2008).

${ }^{65}$ Stavros Tsakryakis, Proportionality: An Assault on Human Rights?, 7 INT'L J. Const. L. 3 (2009).

${ }^{66}$ Lenaerts, supra note 10.
} 
understanding of "essence," leaving no room for proportionality analysis with only one case pointing to a relative understanding of the concept of essence. ${ }^{67}$

In the context of EU law, we ought to turn to wording of Article 52(1) of the Charter. It indeed suggests that the concept of "essence" plays a distinct role from that of the proportionality test. In that sense, the absolute theory spelt out above and according to which the hard core of a right-if and when identified - may not be restricted under any circumstances sits comfortably with a literal reading of Article 52(1) of the Charter. Only if the essence of a fundamental right is not affected is there a need to look at possible justifications and proportionality. As noted by Lenaerts, the absolute view is the one that is closest to the wording of Article 52(1) of the Charter and that may bring most added value to the concept of "essence." ${ }^{8}$ Nevertheless, as Tridimas and Gentile also observe, this view is actually very difficult to put into practice. It is very hard to distinguish a right's core from its periphery. ${ }^{69}$

In turn, the difficulties of identifying the substantive content of the "essence" of Charter rights affect the function of the concept of "essence." As powerfully argued by Tridimas and Gentile, the enquiry into an encroachment on the essence of EU fundamental rights most often results from a preliminary balancing process akin to a proportionality test. ${ }^{70}$ This is demonstrated by Muir's analysis of the references to the concept of "essence" in the cases of Léger and Fries on the fundamental right to equal treatment. ${ }^{71}$ Husovec also highlights that any reference to essence in the case-law of the CJEU on intellectual property rights is only pointing towards a higher level of scrutiny, but not towards an unavoidable core of rights which may not be abolished by the legislator. ${ }^{72}$ Situations in the hard core would have to essentially be cases when no compensation can be offered to offset the interference because the taking away of rights is always considered disproportionate. ${ }^{73}$ It is also noticeable that the tenants of the absolute theory themselves heavily rely on expressions akin to a proportionality analysis in the analysis of attacks on the "essence" of Charter rights itself. In the article by Lenaerts, for instance, the vocabulary from the Court's cases on the "essence" often revolves around a question of degree: "Serious and intrusive," "limited to certain aspects," "intensity, but also extent, of the limitation." "4

One way around this problem, concerned with distinguishing an infringement of the essence from a traditional proportionality analysis, is to adopt a method for the identification of the "essence" of a right that is based on a risk of extinction of the right. This is what is proposed by Brkan, as well as to some extent by Lenaerts. Yet again, while this approach allows us to escape the need to define the substantive content of a right, it could easily be subsumed into a proportionality test. Any restriction to a right that endangers its existence is disproportionate. Alternatively, threatening to extinguish a fundamental right will have an impact on the effectiveness of the related EU right. The principle of effectiveness prohibits behavior at national level that would result in extinguishing an EU right. For instance, in the past, the absence of a judicial remedy for the enforcement of an EU right was understood as an infringement of the Member States' duty to ensure the effective protection of related EU rights. ${ }^{75}$ As noted by Gutman today, the absence of a judicial remedy is understood to bear on the "essence" of the fundamental right to effective judicial protection. ${ }^{76}$ The principle of effectiveness finds its origins in the Member

\footnotetext{
${ }^{67}$ Thielbörger, supra note 8 .

${ }^{68}$ Lenaerts, supra note 10.

${ }^{69}$ Tridimas \& Gentile, supra note 12.

${ }^{70}$ Tridimas \& Gentile, supra note 12.

${ }^{71}$ Muir, supra note 41.

${ }^{72}$ Husovec, supra note 60.

${ }^{73}$ We see no such case-law before the ECtHR or CJEU at this point.

${ }^{74}$ Lenaerts, supra note 10.

${ }^{75}$ E.g., Case C-222/84, Johnston v. Chief Constable of the Royal Ulster Constabulary, 1986 E.C.R. 01651, para. 19.; Case C-222/86, Unectef v. Heylens, 1987 E.C.R. 04097, para. 15.

${ }^{76}$ Gutman, supra note 52 , at Sections II and III.
} 
State's duty of loyal cooperation. As such, it warrants the protection of fundamental rights that form the subject matter of specific EU policies to which Member States are expected to actively contribute, such as the right to data protection or equal treatment between men and women. The principle of effectiveness may therefore at times have a similar function in protecting a fundamental right as the "essence" does.

If it is true that either proportionality or, as the case may be, the principle of effectiveness already provide similar or equivalent tools to weed out the most egregious limitations on fundamental rights - the notion of essence could simply be redundant. It may change the order of fundamental rights review - for example, by encouraging the judiciary to first consider existential threats to a right demanded by the literal wording of Article 52(1) CFEU-but, by replicating the substance of existing legal tests, do little to change the substance and outcomes of such review.

There is one further concern related to the technique by which one would look at the breadth of the breach to define an encroachment on the "essence" of the right. This approach sheds light on how the essence of EU fundamental rights relates to other existing elements of EU law. There is an important conceptual danger with conflating proportionality or degree or breath of a breach of a right with a quest for the "essence" of a right. The equality law example, as discussed by Muir, suggests a troubling aspect to this approach. ${ }^{77}$ The question of the "severity" of a fundamental rights limitation should be connected to the number of people affected by it-an idea that runs contrary to the entire notion of fundamental rights protection and particularly its use to protect minorities.

\section{The Institutional Implications of Reliance on the Concept of "Essence"}

The concept of essence further raises institutional issues: Who defines the concept of essence? As mentioned above, if this task is left to judges, there will be a choice to be made between an objective and subjective approach to the task. As Tridimas and Gentile highlight, there are significant differences between articulating this core from the perspective of the rights-holder or doing so from the perspective of the polity and its overall constitutional goals. ${ }^{78}$ The latter perspective seems to suggest that a "right by right" approach does not avoid, but may even require, a more systemic approach to understanding the essence concept in addition.

One may query what role the legislature should have in defining the essence of rights. Thielbörger attributes the judicial role in the concept of essence in international law to, amongst other things, "the lack of a legislator in international law." ${ }^{79}$ He suggests that where there is a legislator, as there is in the EU, "this legislator can spell out clear and concrete minimum levels of protection." ${ }^{80}$ In contrast, Husovec cites Advocate General Szpunar in Pelham and Spiegel Online when he suggests that fundamental rights ought to play "a sort of ultima ratio [role] which cannot justify departing from the wording of the relevant [legislative] provisions except in cases of gross violation of the essence of a fundamental right." 81 This suggests that interference with essence-and only interference with essence-could justify judicial intervention into legislative choices. Yet this leaves open what role the legislature itself should play in defining "essence."

A related consideration is the role of Member States in the definition of essence. It is not clear, given the diverse sources of EU fundamental rights law, whether an essence for each right should be identified as an autonomous EU law standard or as one derived from national constitutional traditions. If reference is made to the national level, the degree of "essentialness" of a given right, or a given part of a right, may vary between national contexts. The case-law of the

\footnotetext{
${ }^{77}$ Muir, supra note 41.

${ }^{78}$ Tridimas \& Gentile, supra note 12.

${ }^{79}$ Thielbörger, supra note 8 .

${ }^{80}$ Thielbörger, supra note 8 .

${ }^{81}$ Case C-476/17, Pelham and Others (Dec. 12, 2018), para. 98, http://curia.europa.eu; Case C-516/17, Spiegel Online, (Jan. 10, 2019), para. 62, http://curia.europa.eu.
} 
EctHR - adjudicating a Convention to which all EU states are members-could potentially provide some coherence in this regard. As noted above, however, the contribution of Van Drooghenbroeck and Rizcallah casts doubt on whether the ECtHR will fulfil this role given the Court's "essentially pragmatic and unprincipled approach" to the question and the ensuing doctrinal confusion they describe. ${ }^{82}$

Thus, it can be seen that the concept of "essence" may play a critical, if problematic, role in the vertical relations between the EU, its Member States and related legal orders such as that of the ECtHR, as well as in the horizontal institutional balance between the Court and the legislator. This leaves an obvious question: Who are the institutional players who may be negatively affected by reliance on the concept of "essence" and what could be their objections?

We naturally turn to domestic constitutional orders and the ECtHR to start with. ${ }^{83}$ These legal systems are the natural and initial sources of authority as well as ultimate guardians-in their respective jurisdictions at least-of fundamental rights at the domestic level as well as in the EU. ${ }^{84}$ From their perspective, the concept of "essence" may give support to their approach if the EU "essence" of a right overall matches their own approaches and where case law provides the highest level of protection to a given right or part of a given right. Alternatively, a narrative based on the absolute and uniform protection of the "essence" of rights defined by another actor, when it departs from their approach, may be perceived by domestic courts or the ECtHR as preventing them from exercising their core functions of defining and weighing fundamental values and rights. Greater reliance on the concept of "essence" of EU fundamental rights may be expected to exacerbate the terms of this debate if the concept of "essence" is not carefully articulated in light of domestic constitutional traditions as well as the ECHR.

As noted above, another important institutional actor for whom the debate on the "essence" may have implications is the EU legislator. Lenaerts for instance suggests that secondary EU law may only "determine non-essential elements" of fundamental rights. ${ }^{85}$ For their part, Tridimas and Gentile query whether the concept may function as "a counter-majoritarian residue." 86 The concept indeed can be seen as either limiting the legislators' ability to encroach upon the "essence" of EU fundamental rights or, instead, empowering the legislator to be creative in articulating its vision of fundamental rights in all that does not call into question the "essence" of the right. In that sense, the Court may be encouraging political engagement with fundamental rights ${ }^{87}$ and supporting politically constructive debate on EU fundamental values. ${ }^{88}$ Alternatively, reliance on the concept of "essence," depending on the shape of the narrative may also be perceived precisely as suppressing the ability of political institutions to engage with debates on fundamental rights.

In all these cases, the concept of "essence" carries the capacity to significantly alter both the institutional balance of the EU and the balance with other legal orders. The "essence" of fundamental rights could precisely be seen as a way for the Court to manage conflicts between pluralist and constitutionalist readings of EU rights. ${ }^{89}$ This tension is reflected in the very wording of

\footnotetext{
${ }^{82}$ Von Drooghenbroeck \& Rizcallah, supra note 9.

${ }^{83} \mathrm{We}$ are most grateful to Leonard Besselink for his presentation on "Is the Concept of the Essence of Fundamental Rights Mirrored in European Domestic Constitutional Law?” on the occasion of the conference on which this Special Issue is based. The views expressed in this paragraph are largely inspired from our exchanges on that occasion.

${ }^{84}$ See also Jan Komarek, National Constitutional Courts in the European Constitutional Democracy, 12 INT'L J. CONST. L. 3 (2014); Marco Dani, National Constitutional Courts in the European Constitutional Democracy: A Reply to Jan Komarek, 15 INT'L J. CONST. L. 3 (2017).

${ }^{85}$ Lenaerts, supra note 10.

${ }^{86}$ Tridimas \& Gentile, supra note 12.

${ }^{87}$ Mark Dawson, the Governance of EU Fundamental Rights 47-83 (Cambridge Univ. Press, 2017).

${ }^{88}$ See Mark Dawson, Constitutional Dialogue Between Courts and Legislatures in the European Union: Prospects and Limits, 19 EUr. Pub. L. 2 (2013).

${ }^{89} \mathrm{On}$ this tension, see $i d$.
} 
Article 6 TEU, which anchors EU rights both in EU sources and in national constitutional traditions. This wording suggests a delicate balancing act; while the EU sources suggest a common set of rights, which ought to be guaranteed across the Union, Article 6 (3) TEU and the commitment to respect constitutional identity in Article 4(2) TEU suggest the danger of threatening the role of national institutions in developing their own human rights framework. EU fundamental rights must play a delicate balancing act, contributing to, but not undermining other frameworks - an act which recent controversial decisions of the CJEU have threatened to up-end. ${ }^{90}$

The need to strike the right balance sets an important challenge for the CJEU. It is in many ways natural for the Court to seek to position itself as the ultimate guardian of EU core values, and to seek to interpret the concept of "essence" for that purpose. First, the EU is founded on, inter alia, "the rule of law and respect for human rights." ${ }^{11}$ It is also the role of the CJEU to ensure that "in the interpretation and application of the Treaties the law is observed." 92 Both aspects have long been anchored in the functioning of the EU legal order..$^{93}$ In the words of Tridimas and Gentile, the concept of "essence" may act as a "rallying democratic cause" 94 reflected in Lenaerts's assertion that "the 'essence of fundamental right' is the most fundamental bastion of liberty that the CJEU will never give up." 95 This is very much the reading that can be made of cases such as $L M$, on the deficiencies in the system of justice in Poland, in which the Court ruled that:

The requirement of judicial independence forms part of the essence of the fundamental right to a fair trial, a right which is of cardinal importance as a guarantee that all the rights which individuals derive from EU law will be protected and that the values common to the Member States set out in Article 2 TEU, in particular the value of the rule of law, will be safeguarded $^{96}$

The Court went on to say that "[t]he very existence of effective judicial review designed to ensure compliance with EU law is of the essence of the rule of law."

In such cases, as examined in the contribution by Gutman, access to a judge for the enforcement of Union rights, the discourse on fundamental rights and the debate on the rule of law in the European Union are conflated.

Second, there may be a need to strengthen the Court's narrative on fundamental rights in response to a multitude of constitutional challenges. Domestic constitutional courts have over recent years been relying on the Charter to develop their own definitions of fundamental rights. ${ }^{98}$ Emerging literature on the role of the EU legislator in fleshing out, and contributing to the governance of, fundamental rights may also be perceived as diluting the CJEU's fundamental rights narrative, or as evidence of an increasing "sharing" of fundamental rights responsibilities between legal and political institutions. ${ }^{99}$ Severe criticisms have been raised against the involvement of EU institutions in measures affecting fundamental rights in the context of the responses to the

\footnotetext{
${ }^{90}$ See e.g., Case C-399/11, Melloni v. Ministerio Fiscal, (Feb. 26, 2013), http://curia.europa.eu; Case C-105/14, Taricco and Others, (Sept. 8, 2015), http://curia.europa.eu.

${ }^{91}$ TEU, supra note 2 , at art. 2.

${ }^{92} \mathrm{TEU}$, supra note 2, at art. 19(1).

${ }^{93}$ For instance, see Parti écologiste "Les Verts” v. European Parliament, 1986 E.C.R. 01339, para. 23.

${ }^{94}$ Tridimas \& Gentille, supra note 12.

${ }^{95}$ Lenaerts, supra note 10.

${ }^{96}$ Case C-216/18 PPU (July 25, 2018), para. 48, http://curia.europa.eu [emphasis added].

${ }^{97} I d$. at para 51 [emphasis added]. See also Case C-64/16 Associação Sindical dos Juízes Portugueses v. Tribunal de Contas, (Feb. 27, 2018), http://curia.europa.eu.

${ }^{98}$ See Opinion 4/2018, Challenges and Opportunities for the Implementation of the Charter of Fundamental Rights (EU Fundamental Rights Agency, 2018), at 43-47.

${ }^{99}$ Dawson, supra note 89; Elise Muir, EU Equality Law: The First Fundamental Rights Policy of the EU (Oxford Univ. Press 2018).
} 
economic and migration crises, placed beyond the reach of CJEU case law. ${ }^{100}$ Finally, the influence of the European Convention for Human Rights may be seen as weakening and thereby making space for a stronger narrative on fundamental rights from the CJEU. The "essence" is one vehicle to provide such a narrative.

\section{E. Future Implications and Prospects}

What is the future of the doctrine of the "essence" of fundamental rights? This depends in large part on two decisive sets of actors. The first actor is the CJEU itself. Much research in EU law currently focuses on landmark judgments. ${ }^{101}$ One question is whether Schrems constitutes such a landmark judgment in constituting a decisive turning point in how the Court approaches fundamental rights adjudication. For this to be the case requires the essence test to be generalized far beyond the ad hoc and differentiated picture identified in the contributions to this special issue to become a standard means of evaluating Charter violations. This can only be considered in time: Will the standard EU law textbook of 2025 ask students of EU law, when faced with hypothetical cases involving rights violations, to first assess whether the "essence" of a right has been violated, or will such students instead focus on the justifications for and proportionality of such a breach?

The second set of decisive actors are those that have to respond to the Court's case-law. Following Schrems, will the EU's political bodies, when proposing or adopting legislation with a fundamental rights dimension, place as an outer boundary for their proposals the Court's case-law on essence? Will they, as we have seen in equality ${ }^{102}$ and data protection law, use this doctrinal innovation as a spur to develop their own policy-making-for example by providing individuals with tools and remedies to elaborate and defend the essence of EU rights within European societies?

A similar set of questions pertains to other legal actors. Following Schrems, will other courts, such as domestic constitutional courts or the ECtHR, view the essence of EU rights as a means of managing the relationship between EU law and their orders-the pluralist "advantage" of essence discussed above-utilizing the preliminary reference procedure in this regard? Or will they instead see it as conflicting with the "irreducible core" of their own legal orders, with essence-given its absolute nature under one reading, limiting the room for "balancing"-creating the perfect breeding ground for conflicts between legal orders that cannot be so easily interpreted away?

If, as indicated above, the rule of law crisis provides an important rationale for introducing or generalizing the "essence" concept, it may also be an important first testing ground in examining how these questions are answered. In his recent opinion in the much discussed upcoming decision of the Court in Commission v. Poland, Attorney General Tanchev relies upon the notion of essence in arguing that Polish measures affecting judicial independence potentially infringe an "essential" component to judicial independence under Article 19(1) TEU. ${ }^{103}$ Such reliance on the essence of this provision makes it far harder for the Polish government to justify its current raft of judicial reforms - potentially also framing the reactions of the other institutions under the ongoing Article 7 procedure. In this sense, the ability of the essence of fundamental rights to attempt to defend fundamental EU values in the Polish case is likely to significantly frame the general receptivity of EU scholarship to its further development in EU law.

\footnotetext{
${ }^{100}$ Claire Kilpatrick, On the Rule of Law and Economic Emergency: The Degradation of Basic Legal Values in Europe's Bailouts, 35 OXford J. Legal STUd. 2 (2015); DAwson, supra note 89, at 185-225.

${ }^{101}$ See e.g., Urška Šadl \& Hendrik Palmer Olsen, Can Quantitative Methods Complement Doctrinal Legal Studies? Using Citation Network and Corpus Linguistic Analysis to Understand International Courts, 30 LEIDEN J. INT'L L. 2 (2017).

${ }^{102}$ See Elise Muir, The Legislative Embedding of the Governance of EU Equality Law, in EU EQUALITY LAW: THE FIRST Fundamental Rights Policy of the EU 144 (Oxford Univ. Press, 2018).

${ }^{103}$ Case C-619/18, Comm'n v. Pol., (Apr. 11, 2019), para. 82, http://curia.europa.eu.
} 
The aspiration of this Special Issue is not to predict how EU law will evolve, but to provide an overview of both the theoretical and doctrinal choices at issue in further developing the essence of EU fundamental rights and a first snapshot of how those choices are being made in particular substantive fields of EU law. We are thankful to our authors for providing the articles that made this possible. 